\title{
Multi-environmental evaluation of winter oilseed rape genotypic performance using mixed models
}

\author{
Jan Bocianowski $(\mathbb{D} \cdot$ Alina Liersch $\mathbb{B}$
}

Received: 19 November 2019/Accepted: 8 March 2021/Published online: 2 April 2021

(C) The Author(s) 2021

\begin{abstract}
The production of winter oilseed rape (WOSR) (Brassica napus) together with increasing seed yields per hectare is one of the strategies for breeding the genetic base of oilseed rape genotypes adapted to different environments. The main objective of this study was to evaluate the genotypic performance of 25 winter oilseed rape genotypes using mixed models. The plant material was examined in five locations in Poland. Field trials were carried out in a randomized complete block design with four replicates. The REML/BLUP was used to estimate genetic parameters. Selection of genotypes was made on the basis of genetic values by the harmonic mean of relative performance these parameters. The mean heritability for genotype had an average value at a high accuracy of selection, while additionally it facilitated selection of agronomically superior individuals. Three restorer lines PN18, PN17 and PN21, CMS ogura line PN64 as well as hybrids PN66 $\times$ PN21 and PN64 $\times$ PN21 characterized good adaptability and stability of seed yield. There were similarities among the statistics
\end{abstract}

J. Bocianowski $(\bowtie)$

Department of Mathematical and Statistical Methods, Poznań University of Life Sciences, Wojska Polskiego 28, 60-637 Poznan, Poland

e-mail: jan.bocianowski@up.poznan.pl

A. Liersch

Department of Oilseed Crops, Plant Breeding and Acclimatization Institute - National Research Institute,

Strzeszyńska 36, 60-479 Poznan, Poland $(\hat{\mu}+\hat{g})$, adaptability and stability of genetic values in the discrimination of the most productive genotypes by best linear unbiased predictor analysis. Mixed models can be recommended as a potential selection method for the inclusion of new plant material in different oilseed rape breeding programs aimed at developing new WOSR cultivars.

Keywords Brassica napus L. · Adaptability · Productivity · Restricted maximum likelihood/best linear unbiased predictor $\cdot$ Stability
Abbreviations
BLUP Best linear unbiased predictor
MHPRVG Stability and adaptability of genetic values
MHVG Stability of genetic values
PRVG Adaptability of genetic values
REML REstricted Maximum Likelihood

\section{Introduction}

Winter oilseed rape (WOSR, rapeseed, canola) (Brassica napus L.) is the most important oil and protein crop in Europe. In Poland in 2017 the cultivated area was 914 thousand ha with an average seed yield of $2950 \mathrm{t} \mathrm{ha}^{-1}$ (www.fao.org.2019). Double-low quality cultivars with zero erucic acid and low glucosinolate 
contents are a source of the healthiest vegetable oils with a balanced fatty acid composition (SzydłowskaCzerniak et al. 2011). Its oil is also used as a green biofuel, an animal feed component and a valuable material for many products in chemical and pharmaceutical industries (lubricants, hydraulic oils, soap and biodegradable plastics) (Friedt and Snowdon 2009; Huang et al. 2016). The residual meal from oilseed rape seeds after oil extraction provides a protein-rich (38-44\%) animal feed. Thanks to its nutritional value oilseed rape may be considered as an alternative source of protein to replace soya in countries with moderate climate, such as Poland. This meal represents a favorable composition of amino acids, including comparatively high contents of the essential sulfuric amino acids: methionine and cysteine (Downey and Bell 1991). In addition, the meal is rich in minerals, particularly $\mathrm{Ca}, \mathrm{Mg}$ and $\mathrm{P}$, and contains vitamins B4 and E (Thies 1994).

The constantly growing demand for high-quality human food and animal feed is a challenge for researchers, farmers and food producers. The main objective in many WOSR breeding programs is to develop high yielding cultivars, with satisfactory resistance to biotic and abiotic stresses and good seed quality traits (oil and protein contents, fatty acid composition as well as low glucosinolate and fiber levels) (Körber et al. 2016). Many traits of agronomic importance are controlled by multiple genes of small effect, while their phenotypic expressions is strongly affected by non-genetic factors as well as genotype by environment interactions (Piepho 1994; Nowosad et al. 2016; Werner et al. 2018; Bocianowski et al. 2019a, 2020; Liersch et al. 2020).

In many plant species the multi-environmental analysis of breeding materials is extensively used for the characterization of germplasm collections from an agronomic point of view. Apart from the genotypes, the environment and the environment $\times$ genotype interactions also show information concerning the particular genotype variation in particular environment, as well as its adaptability and stability (Nowosad et al. 2017; Bocianowski et al. 2019b, c). Reliable performance prediction of combinations of parental lines (CMS ogura, restorer lines) is a key factor for success in $\mathrm{F}_{1} \mathrm{CMS}$ ogura hybrid breeding programs (Werner et al. 2018). Testing of the response of parental lines and hybrids to diverse environmental conditions during growing seasons determines their essential traits (e.g. vigor, yield, yield-related traits or seed quality traits). Complex traits, such as e.g. seed yield, yield components and oil content in seeds are controlled by multiple genetic factors, which expression is the result of the interaction between the genotype and the environment. Studies on GEIs for agronomic traits in oilseed rape are frequent (Seyis et al. 2006; Nowosad et al. 2016; Bocianowski et al. 2019d). The aim of a breeding strategy in oilseed rape (parental forms of CMS ogura hybrids, semi-resythesized lines and genotypes with other quality traits) is to generate stable genotypes with the capacity to adapt to different soil and climatic conditions. Szała et al. (2019) and Spasibionek et al. (2020) reported that seed yields of CMS ogura F1 hybrids as well as WOSR breeding lines with a modified fatty acid composition of seed oil were the result of the effect of genotypes, the environment and their interactions. Additionally, Fletcher et al. (2015) indicated that Brassica napus lines should be grown under diverse growing conditions and different geographies to understand the role of the environment in agronomically important traits and their interaction with the underlying genetic factors.

Restricted maximum likelihood/best linear unbiased predictor (REML/BLUP) analysis makes it possible to consider correlated errors within locations as well as the stability and adaptability in superior genotype selection. Thus, genetic values may be obtained, instability may be calculated and the values may be applied to any number of environments. In addition, this method generates results in the unit of a given observed trait that can be directly interpreted as genetic values. Selection for seed yield and yield stability was based on the harmonic mean of the relative performance of genotypic predicted values. This refers to the relative performance of the genotypic values in the studied environment. In this case, the predicted genotypic values are expressed as a proportion of the overall average for each location and, subsequently, an average value of this ratio for all locations is obtained. Simultaneous selection for adaptability, seed yield and phenotypic stability in the context of mixed models can be performed using the MHPRVG method (Mohammadi and Amri 2008; Mendes et al. 2012).

This method has been used to interpret adaptability and genotypic stability of such crops as the common bean (Lin and Binns 1988), sugarcane (Bajpai and 
Kumar 2005), wheat (Mohammadi and Amri 2008) and popcorn cultivars (Scapim et al. 2010). However, its application in winter oilseed rape has been limited.

Genotypic effects in the MHPRVG model are random. Therefore, this model shows genotypic, rather than phenotypic, adaptability and stability. The model analyzes adaptability and stability in the selection of individuals within progenies and provides genetic values after instability is excluded, while additionally it may be potentially used to different environments. So, the main objective of this study was to estimations the genotypic parameters of winter oilseed rape parental lines and experimental hybrids CMS ogura (Brassica napus L.) through mixed models proposed by de Souza et al. (2018).

\section{Material and methods}

The plant material used in this study comprised open pollinated cultivar Californium and Hercules $F_{1}-$ hybrid cultivar, 15 Polish Ogura $\mathrm{F}_{1}$ hybrids under development $\quad[$ PN64 $\times$ PN17, $\quad$ PN64 $\times$ PN18, PN64 $\times$ PN21, $\quad$ PN64 $\times$ PN05, $\quad$ PN64 $\times$ PN07, PN66 $\times$ PN17, $\quad$ PN66 $\times$ PN18, $\quad$ PN66 $\times$ PN21, PN66 $\times$ PN05, $\quad$ PN66 $\times$ PN07, $\quad$ PN68 $\times$ PN17, PN68 $\times$ PN18, $\quad$ PN68 $\times$ PN21, $\quad$ PN68 $\times$ PN05 PN68 $\times$ PN07] and their eight parental lines, i.e. three Ogura CMS lines-PN64, PN66, PN68 and five restorer lines-PN05, PN07, PN17, PN18, PN21].

The plant material was tested in five locations: an experimental station in Bąków (E1), the Opolskie Province, and four experimental stations in the Wielkopolska Province-Borowo (E2), Łagiewniki (E3), Małyszyn (E4) and Zielęcin (E5). Our study was arranged in a randomized complete block design with four replicates. Plot size was four rows $\times 0.30 \mathrm{~m}$ row spacing and sowing density of 80 seeds $\mathrm{m}^{-2}$. Full chemical plant protection of the crop was applied. Other agronomical practices were optimal for local agroecological conditions in all the investigated seasons. Soil types, previous crops and soil $\mathrm{pH}$ were the same as in Nowosad et al. (2016). Weather conditions in Poland varied moderately during the investigated growing seasons of 2006/2007, $2007 / 2008$ and 2008/2009. Precipitation at the experimental sites from August to July was $731 \mathrm{~mm}$ in Bąków, $681 \mathrm{~mm}$ in Borowo, $559 \mathrm{~mm}$ in Łagiewniki, $588 \mathrm{~mm}$ in Małyszyn and $514 \mathrm{~mm}$ in Zielęcin, respectively. Mean annual temperature during the growing seasons (from August to July) were, respectively, $7.2{ }^{\circ} \mathrm{C}$ in Bạków, $11.8{ }^{\circ} \mathrm{C}$ in Borowo, $9.6{ }^{\circ} \mathrm{C}$ in Łagiewniki, $9.2^{\circ} \mathrm{C}$ in Małyszyn and $10.5^{\circ} \mathrm{C}$ in Zielęcin (Table 1).

Seeds were harvested at the seed maturity stage using a plot harvester. Seed yields per plot of $10.0 \mathrm{~m}^{2}$ (Borowo and Bạków), $12.0 \mathrm{~m}^{2}$ (Zielęcin), $9.6 \mathrm{~m}^{2}$ (Łagiewniki) and $11.2 \mathrm{~m}^{2}$ (Małyszyn) were measured and converted to $\mathrm{tha}^{-1}$ for our statistical analyses.

The genetic parameters and the genotype-by-environment interaction (GEI) of seed yield were estimated on the basis of mixed modeling in the GenStat software by the model (de Souza et al. 2018):

$\boldsymbol{y}=\boldsymbol{X b}+\boldsymbol{Z g}+\boldsymbol{W c}+\boldsymbol{e}$,

where $\boldsymbol{y}$ is the vector of seed yield values; $\boldsymbol{b}$ is the vector of the fixed block effects within particular environments; $\boldsymbol{g}$ is the vector of genotype random effects; $\boldsymbol{c}$ is the vector of random GEI effects; $\mathbf{e}$ is the vector of random errors, $\boldsymbol{X}, \boldsymbol{Z}$ and $\boldsymbol{W}$ are the incidence matrices of blocks, genotypes and GEI, respectively. We assumed distributions and structures of means (E) and variances (Var) as:

$E\left[\begin{array}{l}\boldsymbol{y} \\ \boldsymbol{g} \\ \boldsymbol{c} \\ \boldsymbol{e}\end{array}\right]=\left[\begin{array}{l}\boldsymbol{X} \boldsymbol{b} \\ 0 \\ 0 \\ 0\end{array}\right] ; \quad \operatorname{Var}\left[\begin{array}{l}\boldsymbol{g} \\ \boldsymbol{c} \\ \boldsymbol{e}\end{array}\right]=\left[\begin{array}{lll}\boldsymbol{I} \sigma_{g}^{2} & 0 & 0 \\ 0 & \boldsymbol{I} \sigma_{c}^{2} & 0 \\ 0 & 0 & \boldsymbol{I} \sigma_{e}^{2}\end{array}\right]$.

Model adjustment was made on the basis of mixed model equations (de Souza et al. 2018):

$$
\left[\begin{array}{lll}
\boldsymbol{X}^{\prime} \boldsymbol{X} & \boldsymbol{X}^{\prime} \boldsymbol{Z} & \boldsymbol{X}^{\prime} \boldsymbol{W} \\
\boldsymbol{Z}^{\prime} \boldsymbol{X} & \boldsymbol{Z}^{\prime} \boldsymbol{Z}+\boldsymbol{I} \lambda_{1} & \boldsymbol{Z}^{\prime} \boldsymbol{W} \\
\boldsymbol{W}^{\prime} \boldsymbol{X} & \boldsymbol{W}^{\prime} \boldsymbol{Z} & \boldsymbol{W}^{\prime} \boldsymbol{W}+\boldsymbol{I} \lambda_{2}
\end{array}\right]\left[\begin{array}{l}
\hat{\boldsymbol{b}} \\
\hat{\boldsymbol{g}} \\
\hat{\boldsymbol{c}}
\end{array}\right]=\left[\begin{array}{l}
\boldsymbol{X}^{\prime} \boldsymbol{y} \\
\boldsymbol{Z}^{\prime} \boldsymbol{y} \\
\boldsymbol{W}^{\prime} \boldsymbol{y}
\end{array}\right],
$$

where $\lambda_{1}=\frac{\sigma_{e}^{2}}{\sigma_{g}^{2}}=\frac{\left(1-h_{g}^{2}-c^{2}\right)}{h_{g}^{2}}, \lambda_{2}=\frac{\sigma_{e}^{2}}{\sigma_{c}^{2}}=\frac{\left(1-h_{g}^{2}-c^{2}\right)}{c_{g}^{2}}, h_{g}^{2}-$ the individual heritability in the broad sense, $c^{2}=$ $\frac{\sigma_{c}^{2}}{\left(\sigma_{g}^{2}+\sigma_{c}^{2}+\sigma_{e}^{2}\right)}$ is the coefficient of determination of the GEI effects; $\sigma_{g}^{2}$ - the genotypic variance, $\sigma_{c}^{2}$ - the GEI variance, $\sigma_{e}^{2}$-the residual variance between plots, $c_{g}^{2}$ - the coefficient of determination of the genotypic effects, $\hat{r}_{g l o c}=\frac{\sigma_{c}^{2}}{\left(\sigma_{g}^{2}+\sigma_{c}^{2}\right)}=\frac{h_{g}^{2}}{\left(h_{g}^{2}+c^{2}\right)}$ the genotypic correlation for genotypes, by environments, 
Table 1 Weather conditions in Bąków, Borowo, Łagiewniki, Małyszyn and Zielęcin during the vegetation seasons of winter oilseed rape in 2006/2007-2008/2009 and over an extended period (Nowosad et al. 2016)

\begin{tabular}{|c|c|c|c|c|c|c|c|c|c|c|}
\hline \multirow{2}{*}{$\begin{array}{l}\text { Basic weather } \\
\text { parameters }\end{array}$} & \multicolumn{2}{|l|}{ Bąków } & \multicolumn{2}{|c|}{ Borowo } & \multicolumn{2}{|c|}{ Łagiewniki } & \multicolumn{2}{|c|}{ Małyszyn } & \multicolumn{2}{|c|}{ Zielęcin } \\
\hline & $\begin{array}{l}2008 / \\
2009\end{array}$ & 1957-2009 & $\begin{array}{l}2006 / \\
2007\end{array}$ & 1957-2009 & $\begin{array}{l}2007 / \\
2008\end{array}$ & 1957-2009 & $\begin{array}{l}2008 / \\
2009\end{array}$ & $1957-2009$ & $\begin{array}{l}2007 / \\
2008\end{array}$ & 1957-2009 \\
\hline \multicolumn{11}{|c|}{ Mean temperature $\left[{ }^{\circ} \mathrm{C}\right]$} \\
\hline Annual & 7.2 & 6.8 & 11.8 & 8.8 & 9.6 & 8.5 & 9.2 & 8.5 & 10.5 & 8.9 \\
\hline $\begin{array}{l}\text { Critical season of } \\
\text { autumn }^{\mathrm{a}}\end{array}$ & 7.3 & 6.4 & 11.9 & 8 & 8.2 & 9.6 & 9 & 9.4 & 8.8 & 9.7 \\
\hline $\begin{array}{l}\text { Of the coldest } \\
\text { month of winter }\end{array}$ & $-4.5 /$ & $-2.8 / \mathrm{I}$ & $2.1 / \mathrm{II}$ & $-1.7 / \mathrm{I}$ & $\begin{array}{l}1.0 / \\
\text { XII }\end{array}$ & $-1.5 / \mathrm{I}$ & $-2.0 /$ & $-1.1 / \mathrm{I}$ & $\begin{array}{l}1.7 / \\
\text { XII }\end{array}$ & $-1.1 / \mathrm{I}$ \\
\hline $\begin{array}{l}\text { Critical season of } \\
\text { spring }^{c}\end{array}$ & 13.4 & 13.1 & 17.2 & 14.9 & 15.1 & 14.3 & 15.5 & 13.8 & 16.2 & 14.6 \\
\hline \multicolumn{11}{|c|}{ Sum of precipitation $[\mathrm{mm}]$} \\
\hline In whole year & 731 & 661 & 681 & 538 & 419 & 559 & 588 & 586 & 514 & 594 \\
\hline $\begin{array}{l}\text { In critical season } \\
\text { of autumn }\end{array}$ & 92 & 128 & 90 & 103 & 62 & 101 & 155 & 101 & 93 & 105 \\
\hline $\begin{array}{l}\text { In critical season } \\
\text { of winter }\end{array}$ & 207 & 186 & 174 & 141 & 147 & 157 & 112 & 150 & 231 & 173 \\
\hline $\begin{array}{l}\text { In critical season } \\
\text { of spring }\end{array}$ & 265 & 212 & 167 & 177 & 97 & 191 & 109 & 218 & 143 & 204 \\
\hline \multicolumn{11}{|c|}{ Precipitation in \% of a many years background } \\
\hline In whole year & 111 & 100 & 126 & 100 & 75 & 100 & 100 & 100 & 87 & 100 \\
\hline $\begin{array}{l}\text { In critical season } \\
\text { of autumn }\end{array}$ & 72 & 100 & 87 & 100 & 61 & 100 & 153 & 100 & 89 & 100 \\
\hline $\begin{array}{l}\text { In critical season } \\
\text { of winter }\end{array}$ & 111 & 100 & 123 & 100 & 94 & 100 & 75 & 100 & 134 & 100 \\
\hline $\begin{array}{l}\text { In critical season } \\
\text { of spring }\end{array}$ & 125 & 100 & 94 & 100 & 50 & 100 & 50 & 100 & 70 & 100 \\
\hline
\end{tabular}

${ }^{\mathrm{a}}$ Months: September, October, first and second decades of November

${ }^{b}$ Months: third decade of November, December, January, February and March

${ }^{\mathrm{c}}$ Months: April, May, June and first decade of July

$h_{m g}^{2}=\frac{\sigma_{g}^{2}}{\left(\sigma_{g}^{2}+\sigma_{e}^{2} / J\right)}$ the mean heritability for genotype,

$\hat{r}_{g g}^{2}=\sqrt{\hat{h}_{m g}^{2}}$ - the genotype selection accuracy.

The empirical REML/BLUP predictors of the interaction values is given by $\hat{\mu}+\hat{g}_{i}$, where $\mu$-the general mean value, $\hat{g}_{i}$,- the genotypic effect with lack of the GEI were obtained on the basis of proposed model. For each environment, genotypic values $\left(V_{g}\right)$ are predicted by $\hat{\mu}_{j}+\hat{g}_{i}+(\hat{g} a)_{i j}$, where $\hat{\mu}_{j}$-the mean of the $j$-th environment, $\hat{g}_{i}$ - the genotypic effect from the $i$-th genotype, $(\hat{g a})_{i j}$ - the effect from the GEI on the $i$-th genotype in the $j$-th environment.

Prediction of genotypic values is given by the formula: $\hat{\mu}_{j}+\frac{\left(\frac{\sigma_{g}^{2}+\sigma_{c}^{2}}{n}\right)}{\sigma_{g}^{2}} \hat{g}_{i}$

where $\hat{\mu}$-the general mean, $n$-the number of environments, and $\hat{g}_{i}$ - the genotypic effect of the $i$ th genotype.

Stability of genetic values, MHVG, was calculated by the formula:

$M H V G_{i}=n / \sum_{j=1}^{n}\left(1 / V g_{i j}\right)$,

where $n$ - the number of environments $(n=5), V g_{i j}$ the genotypic value of the $i$-th genotype in the $j$-th 
environment. Adaptability of genetic values, PRVG, was calculated by the formula:

$P R V G_{i}=\frac{1}{n} \sum_{j=1}^{n} \frac{V g_{i j}}{M_{j}}$

where $M_{\mathrm{j}}$-the mean of seed yield in the $j$-th environment.

Selection of genotypes (MHPRVG) was made on the basis of productivity, adaptability and stability and calculated by the formula (de Souza et al. 2018):

$M H P R V G_{i}=\frac{V g_{i j}}{n}$.

Selection of the best genotypes was made on the basis of the MHPRVG values and on three criteria: (1) genetic values predicted across the locations with lack of interaction effects, (2) genetic value predicted with the GEI, and (3) selection on the basis of adaptability, production and stability.

\section{Results and discussion}

A prerequisite for the achievement of genetic progress in plant breeding is to use biometric methods and advanced biotechnology techniques (in vitro cultures, molecular biology). The process of breeding hybrid varieties requires a large number of cross-pollination combinations of parental lines and their evaluation in field trials in terms of general and specific combining ability, with simultaneously very careful selection of the components based on a number of qualitative characteristics and good adaptability for different environments.

Genetically, OSR is an allopolyploid (genome AACC, $2 n=38$ ) and contains full genomes of turnip rape and cabbage. The most important rapeseed breeding efforts include improvement of yielding ability via an introduction of hybrid varieties into cultivation, and an improvement of seed quality. Table 2 presents the WOSR genetic structure, which is divided by predictors of mean component and estimates of variance components. Intensive phenotyping in multi-environmental trials may provide the most desirable information to broaden our understanding of important complex traits such as seed development characters, biotic and abiotic stress tolerance and the manifestation of yield characters in oilseed rape
(Friedt and Snowdon 2009). This set of information should be a definite priority in order to facilitate selection of economically important traits, providing both researchers and breeders with an additional tool increasing the efficiency of the breeding process.

Seed yield, as well as seed quality parameters such as oil, protein and glucosinolate contents are strongly influenced by the environment (Quarrie et al. 2006; Nowosad et al. 2016; Bocianowski et al. 2019b) and the $C V_{e}$ result (45.17) (Pereira et al. 2018) (Table 2). High $C V_{g}$ values are desirable, since $C V_{g}$ defines the size of the genetic variation in selection process (Fogaça et al. 2012). The genetic variation coefficient is equal to $41.01 \%$ and showed that the median portion of genetic variances was extracted from the total phenotypic variance. Similar results were obtained by de Souza et al. (2018), who used the same method and mixed models for 14 genotypes of carioca bean in four locations. Torres et al. (2016) and Rocha et al. (2017) obtained similar results for seed yield in oilseed rape genotypes in multi-environments experiments (Szała et al. 2019).

Joint assessment of $C V_{e}$ and $C V_{g}$ is relevant to breeding programs based on selection by the effect of selective accuracy $\left(\hat{r}_{g g}\right)$. In the current study accuracy reached $91.0 \%$, which is a high value. Obtained results showed compatibility of the genotypic values with real genotype values, thus ensuring better selection of winter oilseed rape (Brassica napus L.) genotypes to seed yield.

Heritability is one of the most important genetic parameters, since it measures the fraction of phenotypic variation of inheritable nature and can be explored in selection processes (Würschum et al. 2012). The mean heritability for genotype $\left(\hat{h}_{m g}^{2}\right)$ is estimated when means are used as selection criteria. The heritability value (0.80) obtained in this study provided grounds for showing that selection of the best genotypes can be based on predicted genotypic values.

The heritability in the broad sense $\left(\hat{h}_{g}^{2}\right)$ was estimated as $0.11 \pm 0.04$. The size of the obtained deviation (0.04) didn't have the estimate to the zero value, which was expected and favorable for the seed yield. Torres et al. (2016) obtained $\hat{h}_{m g}^{2}$ and $\hat{h}_{g}^{2}$ values, similar to our results.

The individual phenotypic variance $\left(\hat{\sigma}_{f}^{2}\right)$ is a summ of the genotypic variance, the residual variance 
Table 2 Estimates of variance component (REML individual) of seed yield $\left(\mathrm{dt} \mathrm{ha}^{-1}\right)$ in 25 winter oilseed rape (Brassica napus L.) genotypes cultivated in five environments
Table 3 Estimates of genotypic value of seed yield $\left(\mathrm{t} \mathrm{ha}^{-1}\right)$ in 25 winter oilseed rape genotypes cultivated in five different locations

\begin{tabular}{ll}
\hline Variance components (REML) individuals & Estimators \\
\hline Genotypic variance, $\hat{\sigma}_{g}^{2}$ & 1.0557 \\
Variance of GEI, $\hat{\sigma}_{c}^{2}$ & 0.2293 \\
Residual variance between plots, $\hat{\sigma}_{e}^{2}$ & 1.2890 \\
Individual phenotypic variance, $\hat{\sigma}_{f}^{2}$ & 2.574 \\
Heritability in the broad sense, $\hat{h}_{g}^{2}$ & $0.11 \pm 0.04$ \\
Heritability of the mean genotype, $\hat{h}_{m g}^{2}$ & 0.80 \\
Accuracy of genotype selection, $\hat{r}_{g g}$ & 0.91 \\
Determination coefficient of the GEI effects, $c^{2}$ & 0.09 \\
Genotypic correlation coefficient across environments, $\hat{r}_{g l o c}$ & 0.18 \\
Coefficient of genetic variation, $C V_{g}(\%)$ & 39.77 \\
Coefficient of experimental variation, $C V_{e}(\%)$ & 45.17 \\
Mean, $\mu$ & 3.969 \\
\hline
\end{tabular}

\begin{tabular}{|c|c|c|c|c|c|c|}
\hline Genotypes & Bạków & Borowo & Łagiewniki & Małyszyn & Zielęcin & Location means \\
\hline Californium & 2.269 & 3.370 & 4.986 & 6.371 & 5.000 & 4.399 \\
\hline Hercules F1 & 3.117 & 3.032 & 5.936 & 8.099 & 6.916 & 5.420 \\
\hline PN17 & 2.597 & 2.000 & 3.446 & 4.112 & 3.146 & 3.060 \\
\hline PN18 & 2.251 & 2.085 & 3.832 & 4.252 & 2.666 & 3.017 \\
\hline PN21 & 2.581 & 2.035 & 3.727 & 4.567 & 3.656 & 3.313 \\
\hline PN5 & 2.494 & 1.715 & 3.368 & 5.245 & 3.979 & 3.360 \\
\hline PN64 & 3.061 & 1.590 & 3.036 & 4.563 & 3.614 & 3.173 \\
\hline PN7 & 2.406 & 1.645 & 3.216 & 4.990 & 3.271 & 3.106 \\
\hline PN64 $\times$ PN17 & 2.845 & 2.943 & 4.553 & 6.546 & 5.229 & 4.423 \\
\hline PN64 $\times$ PN18 & 2.916 & 3.052 & 4.082 & 5.927 & 5.239 & 4.243 \\
\hline PN64 $\times$ PN21 & 2.577 & 2.440 & 4.409 & 6.381 & 5.323 & 4.226 \\
\hline PN64 $\times$ PN5 & 2.281 & 2.525 & 4.208 & 6.112 & 4.739 & 3.973 \\
\hline PN64 $\times$ PN7 & 2.099 & 2.293 & 4.142 & 7.348 & 5.270 & 4.230 \\
\hline PN66 & 2.735 & 2.305 & 3.160 & 5.216 & 3.365 & 3.356 \\
\hline PN66 $\times$ PN17 & 2.987 & 3.295 & 4.408 & 6.189 & 5.145 & 4.405 \\
\hline PN66 $\times$ PN18 & 2.488 & 3.270 & 4.319 & 6.314 & 4.781 & 4.234 \\
\hline PN66 $\times$ PN21 & 2.288 & 3.045 & 4.617 & 6.317 & 5.072 & 4.268 \\
\hline PN66 $\times$ PN5 & 2.665 & 2.388 & 4.106 & 7.027 & 5.510 & 4.339 \\
\hline PN66 $\times$ PN7 & 2.292 & 2.585 & 4.145 & 6.768 & 5.031 & 4.164 \\
\hline PN68 & 2.717 & 1.632 & 2.898 & 5.632 & 3.250 & 3.226 \\
\hline PN68 $\times$ PN17 & 2.485 & 2.555 & 4.732 & 7.188 & 4.677 & 4.327 \\
\hline PN68 $\times$ PN18 & 2.672 & 2.675 & 4.500 & 6.697 & 4.521 & 4.213 \\
\hline PN68 $\times$ PN21 & 3.096 & 2.895 & 4.682 & 6.737 & 4.021 & 4.286 \\
\hline PN68 $\times$ PN5 & 2.580 & 2.477 & 4.715 & 6.520 & 4.822 & 4.223 \\
\hline PN68 $\times$ PN7 & 2.477 & 3.020 & 4.464 & 6.196 & 5.041 & 4.240 \\
\hline Mean & 2.599 & 2.515 & 4.147 & 6.053 & 4.531 & 3.969 \\
\hline
\end{tabular}


between plots and the variance in the GEI. The residual effect variance $\left(\hat{\sigma}_{e}^{2}\right)$ represented $50.01 \%$ of the $\hat{\sigma}_{f}^{2}$ (Table 3). Obtained results had been expected, because seed yield is a quantitative trait determined by many QTLs (Bocianowski et al. 2011) and, consequently, highly influenced by the environment. Seyis et al. (2006) and Wójtowicz (2013) obtained similar results.

The GEI $\left(\hat{\sigma}_{c}^{2}\right)$ variance determine the phenotypic expression of a quantitative trait depending on the individuals' degree of genetic adaptability and/or stability. The $\hat{\sigma}_{c}^{2}=0.2293$ obtained for seed yield corresponded to $8.91 \%$ of the total phenotypic variability, thus allowing to find a genotypic correlation across environments $\left(\hat{r}_{\text {gloc }}=0.18\right)$. Hence, it reinforces the importance of assessing the adaptability and stability of winter oilseed rape genotypes in order to provide accurate recommendations to farmers and breeders in different regions (Kaczmarek et al. 2003).
Three different strategies were used to selection of the best genotypes (Tables 3, 4). Based on the mean genotype in all environments, it may be seen here that cv. Hercules F1 and hybrids PN64 $\times$ PN17 and PN66 $\times$ PN17 were exceptional, because they presented the highest $(\hat{\mu}+\hat{g})$ values: $5.42,4.42$ and $4.41 \mathrm{t}$ $\mathrm{ha}^{-1}$, respectively (Table 3 ). The genetic gains from the selection of these genotypes were $11.16 \%, 7.73 \%$ and $6.17 \%$, respectively.

The $(\hat{\mu}+\hat{g})$ values showed similar to results obtained by methods, wherein PRVG, and MHPRVG were simultaneously used (Table 4). Three restorer lines PN18, PN17 and PN21, CMS ogura line PN64 as well as hybrids PN66 $\times$ PN21 and PN64 $\times$ PN21, selected previously, stood out on the basis of this criterion. Such interaction capitalization is intrinsic to the selection of genotypes presenting greater adaptability and stability in the studied locations.
Table 4 Stability of genetic values (MHVG), adaptability of genetic values (PRVG and PRVGm), and stability and adaptability of genetic values (MHPRVG and MHPRVG $\mu$ ) of 25 winter oilseed rape (Brassica napus L.) genotypes as predicted by BLUP analysis

\begin{tabular}{lrrrll}
\hline Genotypes & MHVG & PRVG & MHPRVG & PRVG $\mu$ & MHPRVG $\mu$ \\
\hline Californium & 10.91 & 0.37 & 12.30 & 0.79 & 12.01 \\
Hercules F1 & 10.73 & 0.32 & 12.87 & 0.74 & 13.14 \\
PN17 & 13.39 & 0.53 & 15.02 & 0.91 & 14.24 \\
PN18 & 13.75 & 0.65 & 18.54 & 1.15 & 19.88 \\
PN21 & 14.71 & 0.53 & 15.53 & 0.93 & 13.58 \\
PN5 & 7.55 & 0.41 & 10.11 & 1.13 & 11.29 \\
PN64 & 10.84 & 0.63 & 15.73 & 1.11 & 14.01 \\
PN7 & 13.52 & 0.56 & 14.72 & 1.26 & 18.21 \\
PN64 × PN17 & 10.46 & 0.30 & 11.37 & 0.77 & 12.00 \\
PN64 × PN18 & 8.87 & 0.25 & 10.15 & 0.72 & 12.99 \\
PN64 × PN21 & 5.73 & 0.51 & 15.47 & 0.94 & 13.11 \\
PN64 × PN5 & 7.51 & 0.31 & 9.62 & 0.95 & 11.24 \\
PN64 × PN7 & 5.59 & 0.29 & 8.83 & 1.13 & 14.00 \\
PN66 & 6.28 & 0.38 & 10.48 & 0.96 & 10.25 \\
PN66 × PN17 & 16.74 & 0.47 & 18.43 & 0.73 & 15.45 \\
PN66 × PN18 & 7.45 & 0.23 & 8.69 & 0.78 & 10.73 \\
PN66 × PN21 & 7.40 & 0.64 & 18.77 & 0.89 & 11.98 \\
PN66 × PN5 & 5.75 & 0.30 & 8.66 & 0.96 & 10.73 \\
PN66 × PN7 & 10.64 & 0.34 & 11.71 & 1.01 & 15.01 \\
PN68 & 11.13 & 0.49 & 14.30 & 1.39 & 19.64 \\
PN68 × PN17 & 9.55 & 0.36 & 12.37 & 0.98 & 14.51 \\
PN68 × PN18 & 9.87 & 0.28 & 10.93 & 0.90 & 14.55 \\
PN68 × PN21 & 12.67 & 0.38 & 13.91 & 0.82 & 14.01 \\
PN68 × PN5 & 9.15 & 0.48 & 14.38 & 0.92 & 12.14 \\
PN68 × PN7 & 9.01 & 0.27 & 9.85 & 0.80 & 11.10 \\
\hline & & & & & \\
\hline
\end{tabular}


Adaptability of genetic values (PRVG) of line PN18 and hybrid PN66 $\times$ PN21 was equal to 0.65 and 0.64 times, respectively. The selection of two the best genotypes by the stability and adaptability of genetic values using the predicted genetic value resulted in a new mean seed yield equal to $1.67 \mathrm{t} \mathrm{ha}^{-1}$ (Table 4). This is lower than value estimated in the selection for mean seed yield of $5.42 \mathrm{t} \mathrm{ha}^{-1}$ in all environments (Table 3).

\section{Conclusion}

The mean heritability of genotype showed average size and high accuracy of selection, while allowing the selection of agronomically the best individuals. Parental lines with the restorer gene $(R f o)$, i.e. PN18, PN17 and PN21, maternal line PN64 as well as hybrids PN66 $\times$ PN21 and PN64 $\times$ PN21 exhibited high seed yield adaptability and stability. There was an agreement between statistics of MHVG, PRVG and MHPRVG in the discrimination of the most productive genotypes, which presented high adaptability and stability. Such results indicated that these genotypes can be part of the selection criteria regularly used in winter oilseed rape breeding programs.

The implementation of the MHPRVG method provides preselection of superior parental lines and hybrid combinations, facilitates the selection process and shortens the breeding cycle. A promising MHPRVG method focusses selection on breeding materials and aims to predict parental lines with the highest potential to produce high oleic (HO), high yield (HY) and high protein (HP) winter oilseed rape hybrid cultivars well adapted to the changing climate.

Acknowledgements The publication was co-financed within the framework of Ministry of Science and Higher Education programme as "Regional Initiative Excellence" in years 2019-2022, Project No. 005/RID/2018/19. We kindly thank Anna Binczarowska for linguistic support.

\section{Declarations}

Conflict of interest Authors declare that they have no conflict of interest.

Ethical approval This article does not contain any studies with human participants or animals performed by any of the authors.
Open Access This article is licensed under a Creative Commons Attribution 4.0 International License, which permits use, sharing, adaptation, distribution and reproduction in any medium or format, as long as you give appropriate credit to the original author(s) and the source, provide a link to the Creative Commons licence, and indicate if changes were made. The images or other third party material in this article are included in the article's Creative Commons licence, unless indicated otherwise in a credit line to the material. If material is not included in the article's Creative Commons licence and your intended use is not permitted by statutory regulation or exceeds the permitted use, you will need to obtain permission directly from the copyright holder. To view a copy of this licence, visit http://creativecommons.org/licenses/by/4.0/.

\section{References}

Bajpai PK, Kumar R (2005) Comparison of methods for studying genotype $\mathrm{x}$ environment interaction in sugarcane. Sugar Tech 7:129-135

Bocianowski J, Kozak M, Liersch A, Bartkowiak-Broda I (2011) A heuristic method of searching for interesting markers in terms of quantitative traits. Euphytica 181:89-100

Bocianowski J, Księżak J, Nowosad K (2019a) Genotype by environment interaction for seeds yield in pea (Pisum sativum $\mathrm{L}$.) using additive main effects and multiplicative interaction model. Euphytica 215:191

Bocianowski J, Niemann J, Nowosad K (2019b) Genotype-byenvironment interaction for seed quality traits in interspecific cross-derived Brassica lines using additive main effects and multiplicative interaction model. Euphytica 215:7

Bocianowski J, Nowosad K, Szulc P (2019c) Soil tillage methods by years interaction for harvest index of maize (Zea mays L.) using additive main effects and multiplicative interaction model. Acta Agric Scand B-S P 69(1):75-81

Bocianowski J, Warzecha T, Nowosad K, Bathelt R (2019d) Genotype by environment interaction using AMMI model and estimation of additive and epistasis gene effects for 1000-kernel weight in spring barley (Hordeum vulgare L.). J Appl Genet 60(2):127-135

Bocianowski J, Tratwal A, Nowosad K (2020) Genotype by environment interaction for area under the disease-progress curve (AUDPC) value in spring barley using additive main effects and multiplicative interaction model. Australas Plant Pathol 49:525-529

de Souza YP, dos Santos PR, Nascimento MR, da Silva Costa KD, Lima TV, de Oliviera TRA, da Costa AF, Pereira HS, da Silva JW (2018) Assessing the genotypic performance of carioca beans through mixed models. Ciênc Rural 48(7):e20170761

Downey RK, Bell JM (1991) New developments in canola research. In: Shabidi F (ed) Canola and rapeseed-production, chemistry nutrition and processing technology. Van Nostrand Reinhold, New York, pp 37-46

Fletcher RS, Mullen JL, Heilinger A, McKay JK (2015) QTL analysis of root morphology, flowering time, and yield 
reveals trade-offsin response to drought in Brassica napus. J Exp Bot 66(1):245-256

Fogaça LA, Oliveira RA, Cuquel FL, Filho JCB, Vendrame WA, Tombolato AFC (2012) Heritability and genetic correlation in daylily selection. Euphytica 184(3):301-310

Friedt W, Snowdon RJ (2009) Oilseed rape. In: Vollmann J, Rajcan I (eds) Handbook of plant breeding. Oil crops, vol 4. Springer, New York, pp 91-126

Huang XQ, Huang T, Hou GZ, Li L, Hou Y, Lu YH (2016) Identification of QTLs for seed quality traits in rapeseed (Brassica napus L.) using recombinant inbreed lines (RILs). Euphytica 210:1

Kaczmarek J, Kotecki A, Kotowicz L, Weber R (2003) Genotype-environment interaction in yield of winter rape in post registration variety trials. Biul IHAR 226(227):395-403 (in Polish)

Körber N, Bus A, Li J, Parkin IAP, Wittkop B, Snowdon RJ, Stich B (2016) Agronomic and seed quality traits dissected by genome-wide association mapping in Brassica napus. Front Plant Sci 7:386

Liersch A, Bocianowski J, Nowosad K, Mikołajczyk K, Spasibionek S, Wielebski F, Matuszczak M, Szała L, CegielskaTaras T, Sosnowska K, Bartkowiak-Broda I (2020) Effect of genotype $\times$ environment interaction for seed traits in winter oilseed rape (Brassica napus L.). Agriculture 10(12):607

Lin CS, Binns MR (1988) A superiority measure of cultivar performance for cultivar x location data. Can J Plant Sci 68(1):193-198

Mendes FF, Guimarães LJM, Souza JC, Guimarães PEO, Pacheco CAP, de Assis Machado JR, Meirelles WF, da Silva AR, Parentoni SN (2012) Adaptability and stability of maize varieties using mixed model methodology. Crop Breed Appl Biotech 12(2):111-117

Mohammadi R, Amri A (2008) Comparison of parametric and non-parametric methods for selecting stable and adapted durum wheat genotypes in variable environments. Euphytica 159:419-432

Nowosad K, Liersch A, Popławska W, Bocianowski J (2016) Genotype by environment interaction for seed yield in rapeseed (Brassica napus L.) using additive main effects and multiplicative interaction model. Euphytica 208:187-194

Nowosad K, Liersch A, Poplawska W, Bocianowski J (2017) Genotype by environment interaction for oil content in winter oilseed rape (Brassica napus L.) using additive main effects and multiplicative interaction model. Indian J Genet Plant Breed 77(2):293-297

Pereira HS, Faria LC, Wendland A, Costa JGC, Souza TLPO, Melo LC (2018) Genotype by environment for disease resistance and other important agronomic traits supporting the indication of common bean cultivars. Euphytica 214:12

Piepho HP (1994) Best linear unbiased prediction (BLUP) for regional yield trials: a comparison to additive main effects and multiplicative interaction (AMMI) analysis. Theor Appl Genet 89:647-654

Quarrie S, Pekic QS, Radosevic R, Kaminska A, Barnes JD, Leverington M, Ceoloni C, Dodig D (2006) Dissecting a wheat QTL for yield present in a range of environments: from the QTL to candidate genes. J Exp Bot 57:2627-2637

Rocha MM, Damasceno-Silva KJ, de Menezes-Júnior JÂN, de Carvalho HWL, da Costa AF, de Lima JMP, dos Santos JF, de Magalhães Bertini CHC, Passos AR, Morais OM (2017) Yield adaptability and stability of semi-prostrate cowpea genotypes in the Northeast region of Brazil by REML/ BLUP. Rev Ciênc Agron 48(5):879-888

Scapim CA, Pacheco CAP, do Amaral Júnior AT, Vieira RA, Pinto RJB, Conrado TV (2010) Correlations between the stability and adaptability statistics of popcorn cultivars. Euphytica 174:209-218

Seyis F, Friedt W, Lühs W (2006) Yield of Brassica napus L. hybrids developed using resynthesized rapeseed material sown at different locations. Field Crops Res 96:176-180

Spasibionek S, Mikołajczyk K, Ćwiek-Kupczyńska H, Piętka T, Krótka K, Matuszczak M, Nowakowska J, Michalski K, Bartkowiak-Broda I (2020) Marker assisted selection of new high oleic and low linolenic winter oilseed rape (Brassica napus L.) inbreed lines revealing good agricultural value. PLoS ONE 15(6):e0233959

Szała L, Kaczmarek Z, Popławska W, Liersch A, Wójtowicz M, Matuszczak M, Biliński ZR, Sosnowska K, Stefanowicz M, Cegielska-Taras T (2019) Estimation of seed yield in oilseed rape to identify the potential of semi-resynthesized parents for the development of new hybrid cultivars. PLoS ONE 14(4):e0215661

Szydłowska-Czerniak A, Bartkowiak-Broda I, Karlović I, Karlovits G, Szłyk E (2011) Antioxidant capacity, total phenolics, glucosinolates and colour parameters of rapeseed cultivars. Food Chem 127:556-563

Thies W (1994) Die wertbestimmenden Komponenten des Rapsschrotes. Vortr Pflanzenzüchtg 30:89-97

Torres FE, Teodoro PE, Rodrigues EV, Santos A, Corrêa AM, Ceccon G (2016) Simultaneous selection for cowpea (Vigna unguiculata L.) genotypes with adaptability and yield stability using mixed models. Genet Mol Res 15(2):gmr.15028272

Werner CR, Qian L, Voss-Fels KP, Abbadi A, Leckband G, Frish M, Snowdon RJ (2018) Genome-wide regression models considering general and specific combining ability predict hybrid performance in oilseed rape with similar accuracy regardless of trait architecture. Theor Appl Genet 131:299-317

Wójtowicz M (2013) Effect of environmental and agronomical factors on quantity and quality of yield of winter oilseed rape (Brassica napus L.). PBAI-NRI Monogr Diss 45:7-111 (in Polish)

Würschum T, Liu W, Mauer HP, Abel S, Reif JC (2012) Dissecting the genetic architecture of agronomic traits in multiple segregating populations in rapeseed (Brassica napus L.). Theor Appl Genet 124:153-161

www.fao.org (2019)

Publisher's Note Springer Nature remains neutral with regard to jurisdictional claims in published maps and institutional affiliations. 